\title{
Lettuce response to organic and phosphate fertilizers and root mycorrhization
}

\author{
Luis Miguel Brito ${ }^{a}$, Áurea Sampaio ${ }^{b}$, Rui Pinto ${ }^{c}$, Isabel Mourão ${ }^{a}$, and João Coutinho ${ }^{c}$ \\ ${ }^{a}$ Centro de Investigação de Montanha (CIMO), Escola Superior Agrária, Instituto Politécnico de Viana do Castelo, Ponte

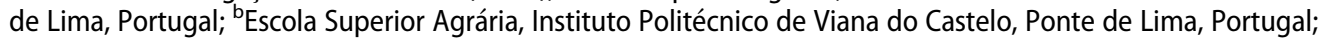 \\ 'C Química, DeBA, EC Vida and Ambiente, Universidade de Trás-os-Montes e Alto Douro, Vila Real, Portugal
}

\begin{abstract}
The response of lettuce to production system, organic and phosphate fertilizers and root mycorrhization, was evaluated in two pot trials with factorial treatment combination of: (i) soil type (from organic and from conventional production systems) and organic fertilizer $\left(0,2\right.$ and $\left.4 \mathrm{tha}^{-1}\right)$ in the first trial; and (ii) mycorrhizal inoculation (mycorrhized and nonmycorrhized plants) and Gafsa phosphate (0, 100 and $\left.200 \mathrm{~kg} \mathrm{P}_{2} \mathrm{O}_{5} \mathrm{ha}^{-1}\right)$ in the second. Lettuce growth decreased with increasing rates of the organic fertilizer because of its very high electrical conductivity $\left(50.1 \mathrm{dS} \mathrm{m}^{-1}\right)$ and lack of maturation. However, the fertilizer harmful effects were minimized in the soil from organic production. The application of Gafsa phosphate significantly increased lettuce yield and nutrient uptake. However, for the highest rate of phosphate, mycorrhized lettuce yield decreased compared to non-mycorrhized lettuce, suggesting that high soil available $P$ may have harmful effects on the activity of mycorrhizal fungi.
\end{abstract}

\section{ARTICLE HISTORY}

Received 27 July 2013

Accepted 14 December 2014

\section{KEYWORDS}

Electrical conductivity; mycorrhizas, nitrogen; $\mathrm{pH}$ value; organic matter; phosphorus

\section{Introduction}

The use of synthetic fertilizers modifies the balance of the soil ecosystem due to changes in soil chemical properties, but also to the destruction of the physical properties and reduction of soil biodiversity (Kibblewhite et al., 2008), decreasing the number of species and increasing the contamination of surface and groundwater (Lampkin, 1990). In contrast to conventional production, organic agriculture (OA) recommends the increased use of on-farm compost and eventually organic fertilizers from outside the farm because these usually have a positive effect on agricultural soils and crop yields. However, despite the benefits of amending the soil with organic fertilizers, farmers must consider the amount and quality of the organic amendments because their indiscriminate application may cause phytotoxicity problems (Brito, 2001).

In most Portuguese soils, phosphorous (P) availability is low. Therefore, $\mathrm{P}$ application is recommended in the form of phosphate fertilizers. Natural phosphates with certification for OA can be as efficient as soluble phosphates (Corrêa et al., 2005) but its efficiency depends on the crop, the rate of application, and soil $\mathrm{pH}$. Natural phosphates are poorly soluble in water and require some acidity of the soil to become soluble over time (Goedert and Sousa, 1984). However, in a highly acidic soil, the solubility of $\mathrm{P}$ decreases due to the precipitation with aluminum, iron and manganese and adsorption with their oxides and hydroxides, and also because soil microbial activity and organic matter (OM) mineralization rate decreases.

CONTACT Luis Miguel Brito miguelbrito@esa.ipvc.pt $\Theta$ Centro de Investigação de Montanha (CIMO), Escola Superior Agrária, Instituto Politécnico de Viana do Castelo, Refóios 4990-706 Ponte de Lima, Portugal. 
The mycorrhizal fungi or mycorrhiza have an important role in nutrient uptake by plants (Marschner, 1996). Not only for the availability of $\mathrm{P}$ but also of other nutrients such as nitrogen (N), potassium (K), calcium (Ca), magnesium $(\mathrm{Mg})$ (Clark and Zeto, 2000) and micronutrients (Liu et al., 2000). The mycorrhiza network considerably increases the volume of soil explored by the roots, which improves the growth of plants in low fertility soils (Marschner, 1996). In contrast, nutrientrich environments were associated with the reduction in the accumulation of nutrients in mycorrhized plants (Clark, 1997). The mycorrhizal colonization has also different effects depending on plant species. Koide et al. (2000), for example, reported that mycorrhizal inoculation increased the production of lettuce, but had no significant effect on chard yield.

Lettuce is a vegetable of great importance in Portugal where is seldom cultivated in organic agriculture. To increase organic lettuce yield producers need to have information to decide on the fertilization for this crop. However, there is lack of experimental results to support fertilizer recommendations in OA. This study evaluated the effects of an organic fertilizer certified for OA applied both to a soil from organic production and to a soil from conventional production, on lettuce growth and nutrient uptake. Simultaneously, the effects of Gafsa phosphate and mycorrhization on lettuce growth and nutrient uptake were quantified to investigate whether the mycorrhization of lettuce may increase lettuce yield in different conditions of soil available phosphorus.

\section{Materials and methods}

Lettuce (Lactuca sativa L.) pot trials were established inside a greenhouse (unheated) in Portugal (39 $49^{\prime} \mathrm{N}, 7^{\circ} 27^{\prime} \mathrm{W}$ and $400 \mathrm{~m}$ of altitude), with fertilizers according to Organic Agriculture EC Regulation No 834/2007 (European Community, 2008). The first trial had a randomized block design (repeated for each harvest) with four blocks and six treatments from the factorial structure of two factors: (i) soil of farms with different production methods (organic and conventional); and (ii) organic fertilizer (0, 2 and $4 \mathrm{t} \mathrm{ha}^{-1}$ ). Both soils of granitic origin were collected at a depth $0-20 \mathrm{~cm}$ in the NW Portugal. The volume of soil in each pot was $6600 \mathrm{~cm}^{3}$. The organic fertilizer was produced with concentrated vinasse waste and chicken manure. According to the commercial label, it should contain $7 \%$ moisture content, $48 \% \mathrm{OM}, 6 \% \mathrm{~N}, 8 \%$ phosphorus pentoxide $\left(\mathrm{P}_{2} \mathrm{O}_{5}\right), 15 \%$ potassium oxide $\left(\mathrm{K}_{2} \mathrm{O}\right), 3.4 \%$ calcium oxide $(\mathrm{CaO})$ and $5 \%$ magnesium oxide $\mathrm{MgO}$.

Lettuce variety Ariel was seeded on peat-blocks consisting of sphagnum peat, and transplantation was made up in the beginning of spring. Transplants were selected randomly within homogeneous plants. The plants were watered frequently to assure that water availability was not a limiting factor for plant growth. During irrigation drained water was replaced in the pots, and weeds were removed immediately after emergency. During this trial, the highest air and soil (at $10 \mathrm{~cm}$ depth) daily mean temperatures were $26.0^{\circ} \mathrm{C}$ and $24.7^{\circ} \mathrm{C}$ respectively, and the lowest was $12.0^{\circ} \mathrm{C}$ both for air and soil. Experimental lettuces were harvested 28 and 45 days after transplantation. For the determination of the weight of the leaves and roots the substrate was removed from the pot and immersed in tap water to separate the soil from the roots. The roots were washed with tap water and dried with a cloth. The washing of the roots was held with the aid of two sieves of $2 \mathrm{~mm}$ mesh in order to minimize the root loss. Shoots were separated from roots and each part was weighted immediately for fresh weight. Dry weight was carried out after drying plant material in a thermoventilated oven at $65^{\circ} \mathrm{C}$ to constant weight.

The second trial had a randomized block design also with four blocks and six treatments from the factorial structure of two factors: Gafsa phosphate with three levels $\left(0,100\right.$ and $\left.200 \mathrm{~kg} \mathrm{P}_{2} \mathrm{O}_{5} \mathrm{ha}^{-1}\right)$ and mycorrhization with two levels (mycorrhized and non-mycorrhized plants). The soil was collected from the organic farm. The Gafsa phosphate, in addition to P had a high content of $\mathrm{Ca}(\mathrm{CaO} 29 \%)$ and the following characteristics: (i) $26.5 \%$ of total phosphorus (expressed in $\mathrm{P}_{2} \mathrm{O}_{5}$ ); (ii) $15 \%$ of phosphorus (expressed in $\mathrm{P}_{2} \mathrm{O}_{5}$ ) soluble in $2 \%$ formic acid; and (iii) milling degree of $90 \%$ passing through a sieve with a mesh of $0.063 \mathrm{~mm}$. Lettuce variety Maravilla de Verano was sown in the beginning of spring. The mycorrhizal inoculum was Glomygel Hortalizas (Mycovitro S.L.) in pack of $250 \mathrm{cc}$ with more than 250 propagules. The inoculum $(1 \mathrm{ml}$ of the gel) was applied close to plant roots with the help of a 
pipette, 7 days after transplantation. Between transplanting and the last harvest, the highest air and soil daily temperatures were respectively 29.5 and $27.2^{\circ} \mathrm{C}$, and the lowest were 13.0 and $15.5^{\circ} \mathrm{C}$. The first and second harvest took place respectively 28 and 53 days after transplantation, using the same procedures reported for the first trial.

Compost dry matter (DM) content (CEN, 1999a), pH value (CEN, 1999b), electrical conductivity (EC; CEN, 1999c) and organic matter (OM) content (CEN, 1999d) were determined by standard procedures. The $\mathrm{DM}$ was determined using a drying oven at a temperature of $75^{\circ} \mathrm{C} \pm 5^{\circ} \mathrm{C}$ with not less than $50 \mathrm{~g}$ of the sample. The $\mathrm{pH}$ was measured with a $\mathrm{pH}$ meter in samples extracted with water at $22^{\circ} \mathrm{C} \pm 3^{\circ} \mathrm{C}$ in an extraction ratio of $1+5(\mathrm{v} / \mathrm{v})$ and the specific EC was measured in the same extract with a conductivity meter. For the $\mathrm{OM}$ determination, samples were ashed for $6 \mathrm{~h}$ at $450^{\circ} \mathrm{C}$ in a muffle furnace. Total $\mathrm{N}$ and $\mathrm{P}$ in the soil, composts and plants (shoots and roots) were measured by molecular spectrophotometry after digestion with sulfuric acid; potassium $(\mathrm{K})$ was measured by flame photometry, and calcium ( $\mathrm{Ca})$, magnesium $(\mathrm{Mg})$ and iron $(\mathrm{Fe})$ by atomic spectrophotometry, after nitricperchloric acid digestion. Mineral $\mathrm{N}$ of fresh soil and compost samples was extracted with potassium chloride $(\mathrm{KCl}) 2 \mathrm{M}$ 1:5. Mineral $\mathrm{N}$ [ammonium $\left(\mathrm{NH}_{4}{ }^{+}-\mathrm{N}\right)$ and nitrate $\left(\mathrm{NO}_{3}{ }^{-}-\mathrm{N}\right)$ ] contents of the extracts were determined by molecular absorption spectrophotometry. For the calculation of the carbon to nitrogen $(\mathrm{C} / \mathrm{N})$ ratio, $\mathrm{C}$ content in the soil was estimated by dividing the OM content by the van Bemmelen factor (1.724) and in compost by a factor of 1.8 (Ogunwande et al., 2008).

Two-way analysis of variance (ANOVAs) were carried out with least significant difference (LSD) post hoc procedures to assess differences on plant growth and nutrient contents between treatments. All statistical calculations were performed using SPSS 15.0 for Windows (SPSS Inc., Chicago, IL, USA). Statistical significance was indicated at a probability level of $\mathrm{P}<0.05$.

\section{Results and discussion}

\section{First trial}

The soil from organic production (SOP) showed higher $\mathrm{OM}$ and $\mathrm{N}$ contents, higher $\mathrm{C} / \mathrm{N}$ ratio and $\mathrm{pH}$ value, and lower $\mathrm{NO}_{3}{ }^{-}-\mathrm{N}$ content, compared to the soil from conventional production (SCP) (Table 1). The organic fertilizer $\mathrm{N}$ and $\mathrm{K}$ contents (Table 1) were considerably lower compared to values reported in the trade label. The electrical conductivity $\left(50.1 \mathrm{dS} \mathrm{m}^{-1}\right)$ and the concentration of $\mathrm{NH}_{4}{ }^{+}-\mathrm{N}(18.4 \mathrm{~g}$ $\mathrm{kg}^{-1} \mathrm{DM}$ ) of this organic fertilizer were extremely high in contrast to the maximum recommended EC less than $3 \mathrm{dS} \mathrm{m}^{-1}$ (Soumaré et al., 2002) and $\mathrm{NH}_{4}{ }^{+}-\mathrm{N}$ less than $0.4 \mathrm{~g} \mathrm{~kg}^{-1} \mathrm{DM}$ (Zucconi and de Bertoldi, 1987), respectively, for compost use as soil amendment.

Lettuce fresh weight was significantly increased in SOP compared to SCP when the organic fertilizer was applied either at the rate of 2 or $4 \mathrm{tha}^{-1}$ (Figure 1). At the first harvest, 28 days after planting, lettuce fresh weight increased significantly with the application of $2 \mathrm{tha}^{-1}$ of organic fertilizer in the SOP, but the same was not true for SCP. In this harvest, with the application of $4 \mathrm{t} \mathrm{ha}^{-1}$ of organic fertilizer, yield decreased in both soils compared with the application of $2 \mathrm{t} \mathrm{ha}^{-1}$. In the second harvest

Table 1. Soils and organic fertilizer characteristics [mean and standard deviation (SD)].

\begin{tabular}{|c|c|c|c|c|c|c|c|c|c|c|c|c|}
\hline & $\begin{array}{c}\mathrm{DM} \\
\%\end{array}$ & $\mathrm{pH}$ & $\begin{array}{c}E C \\
d S m^{-1}\end{array}$ & $\underset{\mathrm{g} \mathrm{kg}^{-1}}{\mathrm{OM}}$ & $\underset{\mathrm{g} \mathrm{kg}^{-1}}{\mathrm{~N}}$ & $\begin{array}{l}\mathrm{NH}_{4}{ }^{+}-\mathrm{N} \\
\mathrm{mg} \mathrm{kg}^{-1}\end{array}$ & $\begin{array}{l}\mathrm{NO}_{3}{ }^{-}-\mathrm{N} \\
\mathrm{mg} \mathrm{kg}^{-1}\end{array}$ & $\mathrm{C} / \mathrm{N}$ & $\begin{array}{c}P \\
\mathrm{~g} \mathrm{~kg}^{-1}\end{array}$ & $\underset{\mathrm{g} \mathrm{kg}^{-1}}{\mathrm{~K}}$ & $\begin{array}{c}\mathrm{Ca} \\
\mathrm{g} \mathrm{kg}^{-1}\end{array}$ & $\begin{array}{c}\mathrm{Mg}^{-1} \\
\mathrm{~g} \mathrm{~kg}^{-1}\end{array}$ \\
\hline \multicolumn{13}{|c|}{ Soil from organic production } \\
\hline Mean & 81.9 & 7.1 & 0.6 & 64.5 & 2.4 & 7 & 46 & 16.4 & 0.9 & 3.8 & 2.3 & 2.0 \\
\hline SD & 0.9 & 0.1 & 0.1 & 0.5 & 0.6 & 0.8 & 2.1 & 0.5 & 0.1 & 2.9 & 1.1 & 1.4 \\
\hline \multicolumn{13}{|c|}{ Soil from conventional production } \\
\hline Mean & 89.3 & 6.3 & 0.6 & 26.5 & 1.7 & 3 & 81 & 9.2 & 0.9 & 5.6 & 2.9 & 3.2 \\
\hline SD & 0.4 & 0.1 & 0.1 & 0.1 & 0.6 & 0.4 & 3.3 & 0.1 & 0.5 & 2.2 & 1.7 & 1.5 \\
\hline \multicolumn{13}{|c|}{ Organic fertilizer } \\
\hline Mean & 92.2 & 5.7 & 50.1 & 546 & 39.5 & 18395 & 80 & 7.7 & 30.3 & 30.0 & 23.3 & 4.0 \\
\hline SD & 0.1 & 0.1 & 1.4 & 11.2 & 11.5 & 6933 & 5 & 0.5 & 7.7 & 13.2 & 8.3 & 0.2 \\
\hline
\end{tabular}

Organic matter $(\mathrm{OM})$ and nutrient contents are expressed on dry matter basis. 

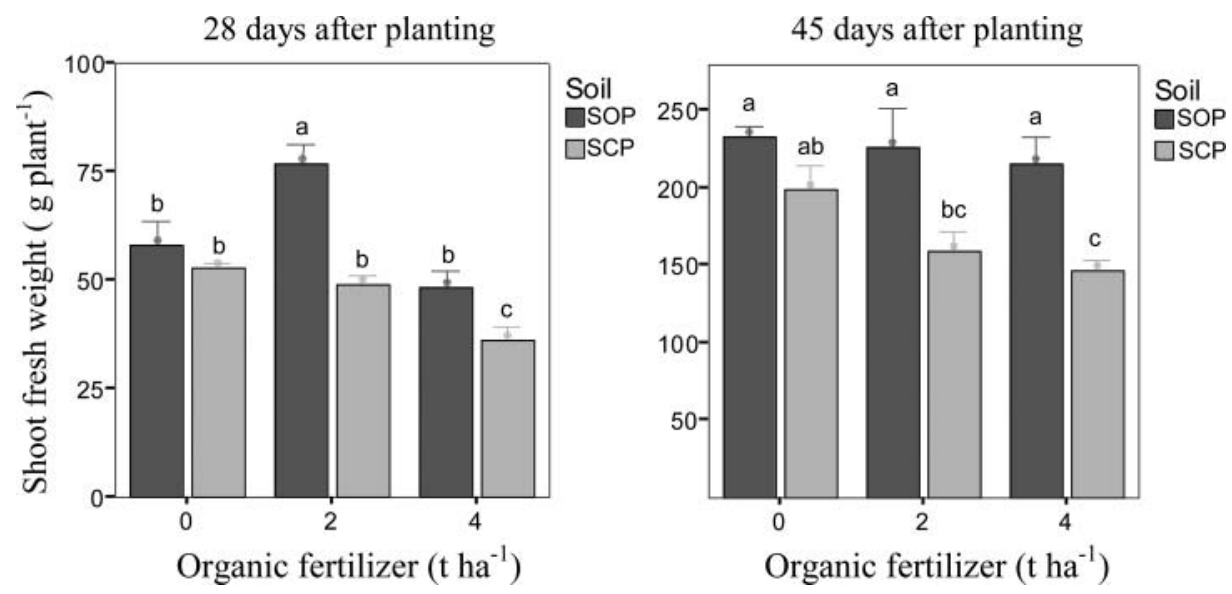

Figure 1. Lettuce shoot fresh weight 28 and 45 days after planting in soil from organic production (SOP) and soil from conventional production (SCP) with organic fertilizer $\left(0,2\right.$ and $\left.4 \mathrm{tha}^{-1}\right)$. Different letters over de bars mean significant weight differences $(P<0.05)$.

there were no significant differences $(\mathrm{P}<0.05)$ between lettuces produced with different rates of organic fertilizer in SOP. However, in SCP lettuce yield significantly decreased with the application of $4 \mathrm{tha}^{-1}$ of organic fertilizer.

The lettuce yield decrease in the SCP with the application of this organic fertilizer can be explained by its extremely high EC value $\left(50.1 \mathrm{dS} \mathrm{m}^{-1}\right)$ which definitely affected water uptake by this salt sensitive species (Maynard and Hochmuth, 1997). The effect of soil salinity to plants is primarily an osmotic effect and high concentrations of salt limit plant growth (Amirjani, 2010). However, it is likely that the detrimental effect of this organic fertilizer resulted from a combination of high EC and other factors such as ammonia toxicity or the liberation of toxic volatile organics which were probably correlated with EC (Brito, 2001). Rapid decomposition of the immature compost causes a decrease of the oxygen $\left(\mathrm{O}_{2}\right)$ concentration in root environment and, therefore, the production of phytotoxic substances, primarily ammonia, ethylene oxide and organic acids (Wong, 1985). Ammonia gas liberation was reported by Katayama et al. (1985) as the main inhibitory factor of immature sludge on plant growth. In the presence of toxic concentrations of ammonia, the plant reacts by lowering its metabolic rate and decreasing enzymatic activities (Sairam and Tyagi, 2004), root respiration and nutrient uptake, and slowing gibberellin and cytokine synthesis and transport.

The toxic effects of this organic fertilizer on lettuce growth and nutrient uptake were minimized in the SOP. Lettuce root fresh weight was also significantly increased for SOP compared to SOC (Table 2). The SOP showed greater resistance to inhibitory effects of the organic fertilizer, probably because of its higher OM content (64.5 $\left.\mathrm{g} \mathrm{kg}^{-1} \mathrm{DM}\right)$ compared to SCP $\left(26.5 \mathrm{~g} \mathrm{~kg}^{-1} \mathrm{DM}\right)$. The high OM content of SOP contributed to a higher cation exchange capacity in this soil in addition to being a reservoir of

Table 2. Fresh weight (FW) of roots (R) and dry matter content (DM) of shoots (S) and roots at harvest $1(\mathrm{H} 1)$ and $2(\mathrm{H} 2)$, respectively 28 and 45 days after planting lettuce, with organic fertilizer application $\left(0,2\right.$ and $\left.4 \mathrm{t} \mathrm{ha}^{-1}\right)$ to soil from organic production (SOP) and soil from conventional production (SCP).

\begin{tabular}{|c|c|c|c|c|c|c|}
\hline \multirow{2}{*}{$\begin{array}{l}\text { Soil } \\
\text { Organic fertilizer }\left(\mathrm{t} \mathrm{ha}^{-1}\right)\end{array}$} & \multicolumn{3}{|c|}{ SOP } & \multicolumn{3}{|c|}{ SCP } \\
\hline & 0 & 2 & 4 & 0 & 2 & 4 \\
\hline FW-R-H1 $\left(\mathrm{g} \mathrm{pl}^{-1}\right)$ & $4.5 \mathrm{a}$ & $4.2 \mathrm{a}$ & $4.0 \mathrm{a}$ & $3.4 \mathrm{a}$ & $3.5 \mathrm{a}$ & $2.9 \mathrm{a}$ \\
\hline FW-R-H2 $\left(\mathrm{g} \mathrm{pl}^{-1}\right)$ & $16.9 \mathrm{a}$ & $16.8 \mathrm{a}$ & $17.9 \mathrm{a}$ & $9.9 b c$ & $12.1 \mathrm{~b}$ & $8.3 c$ \\
\hline DM-S-H1 (\%) & $4.4 \mathrm{~b}$ & $4.3 \mathrm{~b}$ & $5.4 a b$ & $4.4 \mathrm{~b}$ & $5.4 a b$ & $5.7 \mathrm{a}$ \\
\hline DM-S-H2 (\%) & $4.2 \mathrm{~b}$ & $4.7 \mathrm{ab}$ & $4.9 a b$ & $4.7 \mathrm{ab}$ & $5.5 \mathrm{a}$ & $5.2 \mathrm{ab}$ \\
\hline DM-R-H1 (\%) & $7.2 \mathrm{a}$ & $7.2 \mathrm{a}$ & $6.8 \mathrm{a}$ & 8.9 a & $7.9 \mathrm{a}$ & $8.6 \mathrm{a}$ \\
\hline DM-R-H2 (\%) & $8.1 b$ & $6.8 c$ & $6.6 c$ & $10.1 \mathrm{a}$ & $8.5 \mathrm{~b}$ & $9.0 \mathrm{~b}$ \\
\hline
\end{tabular}

Values with common letter in rows are not significantly different at the $5 \%$ level (Ducan Multiple Range Test). 
Table 3. Nutrient contents ( $\mathrm{g} \mathrm{kg}^{-1} \mathrm{DM}$ ) of lettuce shoots 28 and 45 days after planting (Dap), with organic fertilizer application (0, 2 and $4 \mathrm{tha}^{-1}$ ) to soil from organic production (SOP) and soil from conventional production (SCP).

\begin{tabular}{|c|c|c|c|c|c|c|c|}
\hline \multirow[b]{3}{*}{ Nutrient } & \multirow[b]{3}{*}{ Dap } & \multicolumn{6}{|c|}{ Treatment } \\
\hline & & \multicolumn{3}{|c|}{ SOP } & \multicolumn{3}{|c|}{ SCP } \\
\hline & & 0 & 2 & 4 & 0 & 2 & 4 \\
\hline & & & & . & & & \\
\hline \multirow[t]{2}{*}{$N$} & 28 & $36.8 \mathrm{~b}$ & $39.7 \mathrm{ab}$ & $39.1 \mathrm{ab}$ & $40.8 \mathrm{ab}$ & $36.5 \mathrm{~b}$ & $42.9 \mathrm{a}$ \\
\hline & 45 & $22.0 \mathrm{a}$ & $24.6 \mathrm{a}$ & $24.7 \mathrm{a}$ & $26.5 \mathrm{a}$ & $25.4 \mathrm{a}$ & $27.8 \mathrm{a}$ \\
\hline \multirow[t]{2}{*}{$P$} & 28 & $5.4 \mathrm{~b}$ & $5.9 \mathrm{ab}$ & $6.3 \mathrm{a}$ & $5.2 \mathrm{bc}$ & $4.6 \mathrm{c}$ & $5.9 \mathrm{a}$ \\
\hline & 45 & $4.7 \mathrm{ab}$ & $5.5 \mathrm{a}$ & $5.5 \mathrm{a}$ & $3.9 \mathrm{~b}$ & $5.1 \mathrm{ab}$ & $5.7 \mathrm{a}$ \\
\hline \multirow[t]{2}{*}{ K } & 28 & $37.2 \mathrm{ab}$ & $41.0 \mathrm{ab}$ & $49.2 \mathrm{a}$ & $41.9 \mathrm{ab}$ & $30.8 \mathrm{~b}$ & $32.7 \mathrm{~b}$ \\
\hline & 45 & $35.9 \mathrm{a}$ & $38.3 \mathrm{a}$ & $37.8 \mathrm{a}$ & $29.7 \mathrm{a}$ & $29.6 \mathrm{a}$ & $28.7 \mathrm{a}$ \\
\hline \multirow[t]{2}{*}{$\mathrm{Ca}$} & 28 & $21.1 \mathrm{a}$ & $22.3 \mathrm{a}$ & $20.9 a$ & $24.2 \mathrm{a}$ & $22.1 \mathrm{a}$ & $22.0 \mathrm{a}$ \\
\hline & 45 & $17.9 \mathrm{a}$ & $20.6 \mathrm{a}$ & $19.7 \mathrm{a}$ & $20.0 \mathrm{a}$ & $21.5 \mathrm{a}$ & $18.5 \mathrm{a}$ \\
\hline \multirow[t]{2}{*}{$\mathrm{Mg}$} & 28 & $3.1 \mathrm{ab}$ & $3.4 \mathrm{ab}$ & $4.2 \mathrm{a}$ & $3.4 a b$ & $2.8 \mathrm{~b}$ & $3.0 \mathrm{~b}$ \\
\hline & 45 & $5.3 \mathrm{a}$ & $5.9 \mathrm{a}$ & $7.3 \mathrm{a}$ & $6.5 \mathrm{a}$ & $7.6 \mathrm{a}$ & $5.4 \mathrm{a}$ \\
\hline
\end{tabular}

Values with common letter in rows are not significantly different at the 5\% level (Ducan Multiple Range Test).

nutrients (Yilmaz and Alagoz, 2010). The higher OM content is likely to have contributed also to increase soil permeability and water retention capacity (Bayu et al., 2006) satisfying more easily the water demand by the plant. The OM also contributed to decrease soil compaction (Mamman et al., 2007) which favored increased root growth, as found here for lettuces grown on SOP. Therefore, the higher OM content of SOP in comparison to SCP was critical to increase SOP fertility and lettuce yield under phytotoxic conditions.

Most nutrients were taken up between 28 and 45 days after transplantation and the nutrient contents in lettuce shoots were in agreement with the values reported for lettuce by Varennes (2003). The nutrient uptake was higher for $\mathrm{K}$, followed by $\mathrm{N}$ and $\mathrm{Ca}$, compared to $\mathrm{P}$ and $\mathrm{Mg}$. The $\mathrm{N}$ content decreased with age both on lettuce leaves (Table 3) and roots (Table 4). The ratio of $\mathrm{N}$ content of leaves to $\mathrm{N}$ content of roots decreased from the first to the second harvest, but shoot $\mathrm{N}$ content was always higher compared to root $\mathrm{N}$ content. Increases in $\mathrm{P}$ content of lettuce shoot and roots grown with increasing rate of organic fertilizer were generally not statistically significant. The content of $K$ in the first harvest was higher in roots compared to leaves, but the reciprocal was true for the second harvest. The $\mathrm{Ca}$ content was always higher in leaves compared to the roots, whereas the same happen for $\mathrm{Mg}$ in the second harvest but not in the first.

Table 4. Nutrient contents ( $\mathrm{g} \mathrm{kg}^{-1} \mathrm{DM}$ ) of lettuce roots 28 and 45 days after planting (Dap), with organic fertilizer application (0, 2 and $4 \mathrm{tha}^{-1}$ ) to soil from organic production (SOP) and soil from conventional production (SCP).

\begin{tabular}{|c|c|c|c|c|c|c|c|}
\hline \multirow[b]{3}{*}{ Nutrient } & \multirow[b]{3}{*}{ Dap } & \multicolumn{6}{|c|}{ Treatment } \\
\hline & & \multicolumn{3}{|c|}{ SOP } & \multicolumn{3}{|c|}{ SCP } \\
\hline & & 0 & 2 & 4 & 0 & 2 & 4 \\
\hline & & & & $--g$ & & & \\
\hline \multirow[t]{2}{*}{$\mathrm{N}$} & 28 & $24.1 \mathrm{ab}$ & $23.2 \mathrm{ab}$ & $26.0 \mathrm{ab}$ & $21.5 \mathrm{ab}$ & $19.2 \mathrm{~b}$ & $30.5 \mathrm{a}$ \\
\hline & 45 & $17.8 \mathrm{ab}$ & $20.9 \mathrm{ab}$ & $20.2 \mathrm{ab}$ & $16.6 \mathrm{~b}$ & $16.5 \mathrm{~b}$ & $24.3 \mathrm{a}$ \\
\hline \multirow[t]{2}{*}{$P$} & 28 & $6.7 \mathrm{abc}$ & $7.4 \mathrm{ab}$ & $9.0 \mathrm{a}$ & $3.9 \mathrm{c}$ & $5.0 \mathrm{bc}$ & $8.4 \mathrm{ab}$ \\
\hline & 45 & $5.3 a b$ & $7.3 \mathrm{a}$ & $6.9 \mathrm{a}$ & $3.0 \mathrm{c}$ & $4.3 \mathrm{bc}$ & $6.7 \mathrm{a}$ \\
\hline \multirow[t]{2}{*}{ K } & 28 & $73.4 \mathrm{a}$ & $67.3 \mathrm{a}$ & $62.4 \mathrm{a}$ & $40.5 \mathrm{a}$ & $51.5 \mathrm{a}$ & $68.2 \mathrm{a}$ \\
\hline & 45 & $23.8 \mathrm{ab}$ & $22.4 \mathrm{ab}$ & $33.9 \mathrm{a}$ & $17.1 \mathrm{~b}$ & $18.3 \mathrm{~b}$ & $26.6 a b$ \\
\hline \multirow[t]{2}{*}{$\mathrm{Ca}$} & 28 & $10.2 \mathrm{a}$ & $13.7 \mathrm{a}$ & $11.1 \mathrm{a}$ & $12.6 \mathrm{a}$ & $14.4 \mathrm{a}$ & $17.2 \mathrm{a}$ \\
\hline & 45 & $10.5 \mathrm{a}$ & $11.4 \mathrm{a}$ & $9.8 \mathrm{a}$ & $8.4 \mathrm{a}$ & $9.6 \mathrm{a}$ & $9.8 \mathrm{a}$ \\
\hline \multirow[t]{2}{*}{$\mathrm{Mg}$} & 28 & $5.8 \mathrm{a}$ & $6.8 \mathrm{a}$ & $6.8 \mathrm{a}$ & $6.0 \mathrm{a}$ & $7.1 \mathrm{a}$ & $9.6 \mathrm{a}$ \\
\hline & 45 & $4.1 \mathrm{a}$ & $3.7 \mathrm{a}$ & $5.5 \mathrm{a}$ & $4.7 \mathrm{a}$ & $4.9 \mathrm{a}$ & $5.5 \mathrm{a}$ \\
\hline
\end{tabular}

Values with common letter in rows are not significantly different at the 5\% level (Ducan Multiple Range Test). 

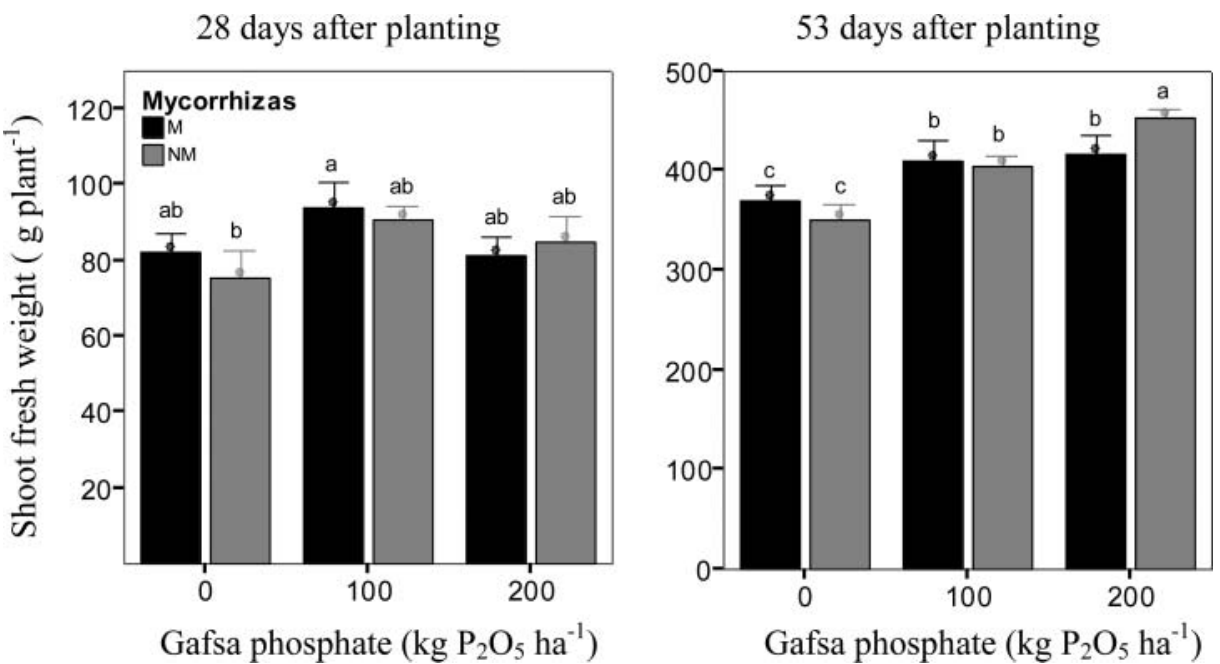

Figure 2. Lettuce shoot fresh weight 28 and 53 days after planting mycorrhized (M) and non-mycorrhized (NM) lettuce, with increasing rates of Gafsa phosphate $\left(0,100\right.$ and $\left.200 \mathrm{~kg} \mathrm{P}_{2} \mathrm{O}_{5} \mathrm{ha}^{-1}\right)$. Different letters over de bars mean significant weight difference $(\mathrm{P}<0.05)$.

\section{Second trial}

Lettuce fresh weight was not significantly different between mycorrhized and non-mycorrhized lettuces for the same rate of Gafsa phosphate application in the first harvest (Figure 2). On the contrary, in the second harvest, for the highest rate of Gafsa phosphate application, yield of mycorrhized plants decreased compared with non-mycorrhized lettuces. Whereas the increase in lettuce yield with phosphate was significant for non-mycorrhized plants between 0 and $100 \mathrm{~kg} \mathrm{ha}^{-1} \mathrm{P}_{2} \mathrm{O}_{5}$ and also between 100 and $200 \mathrm{~kg} \mathrm{ha}^{-1} \mathrm{P}_{2} \mathrm{O}_{5}$, for mycorrhized plants the lettuce yield was not significantly different between the application of 100 and $200 \mathrm{~kg} \mathrm{ha}^{-1} \mathrm{P}_{2} \mathrm{O}_{5}$. Similarly, the dry weight of the leaves of mycorrhized lettuce (results not shown) increased $(\mathrm{P}<0.05)$ from 31.4 to $34.6 \mathrm{~g} \mathrm{plant}^{-1}$ between the rate of application of 0 and $100 \mathrm{~kg} \mathrm{ha}^{-1} \mathrm{P}_{2} \mathrm{O}_{5}$, but did not increase between 100 and $200 \mathrm{~kg} \mathrm{ha}^{-1} \mathrm{P}_{2} \mathrm{O}_{5}$. These results are in agreement with the findings of Azcón et al. (2003). According to this author, the application of higher rates of $\mathrm{N}$ and $\mathrm{P}$ to the soil decreased the uptake of $\mathrm{N}, \mathrm{P}$ and $\mathrm{K}$ in mycorrhized compared to non-mycorrhized plants.

Mycorrhized lettuces without Gafsa phosphate increased final root weight $(\mathrm{P}<0.05)$ compared to nonmycorrhized lettuces (Table 5). At the second harvest, the fresh weight of non-mycorrhized roots increased significantly with the application of 100 and $200 \mathrm{~kg} \mathrm{ha}^{-1} \mathrm{P}_{2} \mathrm{O}_{5}$, respectively $23.7 \%$ and $35.8 \%$ compared to the control treatment $\left(0 \mathrm{~kg} \mathrm{ha}^{-1} \mathrm{P}_{2} \mathrm{O}_{5}\right)$ but the same was not true for mycorrhized roots. The dry matter content of either the leaves or roots did not vary significantly between the different treatments.

Table 5. Fresh weight (FW) of roots (R) and dry matter content (DM) of shoots (S) and roots at harvest $1(\mathrm{H} 1)$ and $2(\mathrm{H} 2)$, respectively 28 and 53 days after planting in mycorrhized (M) and non-mycorrhized (NM) lettuce, with increasing rates of Gafsa phosphate (0, 100 and $200 \mathrm{~kg} \mathrm{P}_{2} \mathrm{O}_{5} \mathrm{ha}^{-1}$ ).

\begin{tabular}{|c|c|c|c|c|c|c|}
\hline \multirow[b]{2}{*}{ Soil $\mathrm{P}_{2} \mathrm{O}_{5}\left(\mathrm{~kg} \mathrm{ha}^{-1}\right)$} & \multicolumn{3}{|c|}{ M } & \multicolumn{3}{|c|}{ NM } \\
\hline & 0 & 100 & 200 & 0 & 100 & 200 \\
\hline FW-R-H1 $\left(\mathrm{g} \mathrm{pl}^{-1}\right)$ & $15.6 \mathrm{a}$ & $16.1 \mathrm{a}$ & $15.2 \mathrm{a}$ & $13.1 \mathrm{a}$ & $15.8 \mathrm{a}$ & $14.9 \mathrm{a}$ \\
\hline FW-R-H2 $\left(\mathrm{g} \mathrm{pl}^{-1}\right)$ & $110.8 \mathrm{a}$ & $104.6 \mathrm{a}$ & $100.5 \mathrm{ab}$ & $85.3 \mathrm{~b}$ & $105.5 \mathrm{a}$ & 115.9 a \\
\hline DM-S-H1 (\%) & $7.0 \mathrm{a}$ & $7.2 \mathrm{a}$ & $7.6 \mathrm{a}$ & $7.1 \mathrm{a}$ & $7.2 \mathrm{a}$ & $7.6 \mathrm{a}$ \\
\hline DM-S-H2 (\%) & $8.5 \mathrm{ab}$ & $8.5 \mathrm{ab}$ & $8.1 \mathrm{~b}$ & $8.8 \mathrm{a}$ & $8.5 \mathrm{ab}$ & $8.2 \mathrm{ab}$ \\
\hline DM-R-H1 (\%) & $7.5 \mathrm{~b}$ & $7.5 \mathrm{~b}$ & $8.0 \mathrm{ab}$ & $8.7 \mathrm{a}$ & $7.6 \mathrm{~b}$ & $7.7 \mathrm{~b}$ \\
\hline $\mathrm{DM}-\mathrm{R}-\mathrm{H} 2(\%)$ & $10.7 \mathrm{a}$ & $12.2 \mathrm{a}$ & $10.6 \mathrm{a}$ & $11.3 \mathrm{a}$ & $11.1 \mathrm{a}$ & $11.0 \mathrm{a}$ \\
\hline
\end{tabular}

Values with common letter in rows are not significantly different at the 5\% level (Ducan Multiple Range Test). 
Table 6. Nutrient contents ( $\mathrm{g} \mathrm{kg}^{-1} \mathrm{DM}$ ) of lettuce shoot 28 and 53 days after planting (Dap) mycorrhized (M) and non-mycorrhized (NM) lettuce, with increasing rates of Gafsa phosphate $\left(0,100\right.$ and $\left.200 \mathrm{~kg} \mathrm{P}_{2} \mathrm{O}_{5} \mathrm{ha}^{-1}\right)$.

\begin{tabular}{|c|c|c|c|c|c|c|c|}
\hline \multirow[b]{3}{*}{ Nutrient } & \multirow[b]{3}{*}{ Dap } & \multicolumn{6}{|c|}{ Treatment } \\
\hline & & \multicolumn{3}{|c|}{$M$} & \multicolumn{3}{|c|}{ NM } \\
\hline & & 0 & 100 & 200 & 0 & 100 & 200 \\
\hline & & & & $-\ldots-g$ & & & \\
\hline \multirow[t]{2}{*}{$N$} & 28 & $18.6 \mathrm{a}$ & 20.9 a & $23.5 \mathrm{a}$ & $16.3 \mathrm{a}$ & $17.2 \mathrm{a}$ & $20.7 \mathrm{a}$ \\
\hline & 53 & $8.8 \mathrm{a}$ & $9.9 \mathrm{a}$ & $10.8 \mathrm{a}$ & $7.0 \mathrm{a}$ & $6.2 \mathrm{a}$ & $8.8 \mathrm{a}$ \\
\hline \multirow[t]{2}{*}{$P$} & 28 & $2.7 \mathrm{a}$ & $2.8 \mathrm{a}$ & $3.3 \mathrm{a}$ & $2.3 \mathrm{a}$ & $2.5 \mathrm{a}$ & $3.0 \mathrm{a}$ \\
\hline & 53 & $2.3 \mathrm{a}$ & $2.4 \mathrm{a}$ & $2.3 \mathrm{a}$ & $1.8 \mathrm{a}$ & $1.5 \mathrm{a}$ & $2.4 \mathrm{a}$ \\
\hline \multirow[t]{2}{*}{ K } & 28 & $26.6 \mathrm{a}$ & $37.0 \mathrm{a}$ & $26.9 \mathrm{a}$ & $23.0 \mathrm{a}$ & $30.7 \mathrm{a}$ & $32.4 \mathrm{a}$ \\
\hline & 53 & $22.7 \mathrm{a}$ & $27.0 \mathrm{a}$ & $33.7 \mathrm{a}$ & $31.3 \mathrm{a}$ & $30.7 \mathrm{a}$ & $32.6 \mathrm{a}$ \\
\hline \multirow[t]{2}{*}{$\mathrm{Ca}$} & 28 & $13.1 b c$ & $19.4 \mathrm{a}$ & $13.7 \mathrm{abc}$ & $12.0 \mathrm{C}$ & $15.8 \mathrm{abc}$ & $18.8 \mathrm{ab}$ \\
\hline & 53 & $8.1 \mathrm{a}$ & $9.1 \mathrm{a}$ & $10.1 \mathrm{a}$ & $8.6 a$ & $9.4 \mathrm{a}$ & $9.0 \mathrm{a}$ \\
\hline \multirow[t]{2}{*}{$\mathrm{Mg}$} & 28 & $4.1 \mathrm{~b}$ & $3.9 \mathrm{~b}$ & $4.2 \mathrm{~b}$ & $3.6 \mathrm{~b}$ & $5.3 \mathrm{~b}$ & $7.5 \mathrm{a}$ \\
\hline & 53 & $2.5 \mathrm{a}$ & $3.1 \mathrm{a}$ & $3.3 \mathrm{a}$ & $2.8 \mathrm{a}$ & $3.1 \mathrm{a}$ & $3.3 \mathrm{a}$ \\
\hline
\end{tabular}

Values with common letter in rows are not significantly different at the 5\% level (Ducan Multiple Range Test).

Lettuce shoot nutrient content showed no significant differences $(\mathrm{P}<0.05)$ between treatments, except for Mg content in the first harvest which increased in non-mycorrhized plants with the application of the highest rate of Gafsa phosphate (Table 6). Shoot N content of mycorrhized lettuces, in both harvests, increased (not significantly) compared to non-mycorrhized lettuces, for the same rate of application of Gafsa phosphate. The same was true for P content, except in the second harvest for the highest rate of Gafsa phosphate. Root nutrient content was not significantly different between treatments, except for $\mathrm{Mg}$ in one treatment.

\section{Conclusions}

The very high EC and ammonia content of the organic fertilizer impaired lettuce growth and nutrient uptake in the SCP. However, the high quality of the SOP demonstrated ability to withstand disturbances caused by this organic fertilizer, and final lettuce yield significantly increased in this soil compared to SCP. Although it is commonly recommended the use of organic fertilizers for organic agriculture in situations of high crop $\mathrm{N}$ demand, it is essential to assess the potential disadvantages of these fertilizers when formulated with poorly matured composts and/or with high electrical conductivity.

The application of increasing rates of Gafsa phosphate increased lettuce yield. However, for mycorrhized plants, the application of $200 \mathrm{~kg} \mathrm{ha}^{-1} \mathrm{P}_{2} \mathrm{O}_{5}$ showed a detrimental effect on lettuce growth and nutrient uptake, compared to non-mycorrhized lettuce. This suggests that high soil available $\mathrm{P}$ content may have harmful effects on the activity of mycorrhizal fungi in lettuce. More research is needed for a better understanding of mycorrhizae growth and activity to recommend their use for organic lettuce production.

\section{References}

Amirjani, M. R. 2010. Effect of salinity stress on growth, mineral composition, proline content, antioxidant enzymes of soybean. American Journal of Plant Physiology 5: 350-360.

Azcón, R., E. Ambrosano, and C. Charest. 2003. Nutrient acquisition in mycorrhizal lettuce plants under different phosphorus and nitrogen concentration. Plant Science 165: 1137-1145.

Bayu, W., N. F. G. Rethman, P. S. Hammes, and G. Alemu. 2006. Application of farmyard manure improved the chemical and physical properties of the soil in a semi-arid area in Ethiopia. Biological Agriculture and Horticulture 24: $293-300$.

Brito, L. M. 2001. Lettuce (Lactuca sativa L.) and cabbage (Brassica oleracea var. Capitata) growth in soil mixed with municipal solid waste compost and paper mill sludge composted with bark. Acta Horticulturae 563: 131-137. 
CEN. 1999a. Soil improvers and growing media, sample preparation for chemical and physical tests, determination of dry matter content, moisture content and laboratory compacted bulk density. Belgium: European Committee for Standardization.

CEN. 1999b. Soil improvers and growing media, determination of $p H$. Belgium: European Committee for Standardization.

CEN. 1999c. Soil improvers and growing media, determination of electrical conductivity. Belgium: European Committee for Standardization.

CEN. 1999d. Soil improvers and growing media, determination of organic matter content and ash. Belgium: European Committee for Standardization.

Clark, R. B. 1997. Arbuscular mycorrhizal adaptation, spore germination, root colonization, and host plant growth and mineral acquisition at low $\mathrm{pH}$. Plant and Soil 192: 15-22.

Clark, R. B., and S. K. Zeto. 2000. Mineral acquisition by arbuscular mycorrhizal plants. Journal of Plant Nutrition 23: 867-902.

Corrêa, R. M., C. W. A. Nascimento, S. K. Souza, F. J. Freire, and G. B. Silva, 2005. Gafsa rock phosphate and triple superphosphate for dry matter production and P uptake by corn. Scientia Agricola 62: 159-164.

European Community. 2008. Laying down detailed rules for the implementation of Council Regulation (EC) No 834/2007 on organic production and labeling of organic products with regard to organic production, labeling and control. Commission Regulation (EC) No 889/2008 of 5 September. Official Journal of the European Communities L250. Belgium: European Community.

Goedert, W. J., and D. M. G. Sousa. 1984. Uso eficiênte de fertilizantes fosfatados [Efficient use of phosphate fertilizers]. In: Simpósio sobre fertilizantes na agricultura brasileira [Symposium on fertilizers in Brazilian agriculture]. Brasília: EMBRAPA.

Katayama, A., M. Hirai, M. Shoda, H. Kubota, and S. Mori. 1985. Inhibitory factor of sewage sludge compost for growth of Komatsuna Brassica campestris L. var. rapiferafroug. Environmental Pollution Series A 38: 45-62.

Kibblewhite, M. G., K. Ritz, and M. J. Swift. 2008. Soil health in agricultural systems. Philosophical Transactions of the Royal Society B: Biological Sciences 363: 685-701.

Koide, R. T., M. D. Goff, and Dickie, I. A. 2000. Component growth efficiencies of mycorrhizal and nonmycorrhizal plants. New Phytologist 148: 163-168.

Lampkin, N. 1990. Organic Farming. Ipswich, U.K.: Farming Press.

Liu, A., C, Hamel, R. I. Hamilton, and B. L. Ma. 2000. Acquisition of Cu, Zn, Mn and Fe by mycorrhizal maize (Zea mays L.) grown in soil at different $\mathrm{P}$ and micronutrient levels. Mycorrhiza 9: 331-336.

Mamman, E., J. O. Ohu, and T. Crowther. 2007. Effects of soil compaction and organic matter on the early growth of maize (Zea mays) in a vertisol. International Agrophysics 21: 367-375.

Marschner, H. 1996. Mineral nutrient acquisition in nonmycorrhizal and mycorrhizal plants. Phyton-Annales Rei Botanicae 36: 61-68.

Maynard, D. N., and G. J. Hochmuth. 1997. Knott's Handbook for Vegetable Growers. New York: John Wiley \& Sons.

Ogunwande, G. A., J. A. Osunade, K. O. Adekalu, and L. A. O. Ogunjimi. 2008. Nitrogen loss in chicken litter compost as affected by carbon to nitrogen ratio and turning frequency. Bioresource Technology 99: 7495-7503.

Sairam, R. K., and A. Tyagi. 2004. Physiology and molecular biology of salinity stress tolerance in plants. Current Science 86: 407-421.

Soumaré, M., A. Demeyer, F. M. G. Tack, and M. G. Verloo. 2002. Chemical characteristics of Malian and Belgian solid waste compost. Bioresource Technology 81: 97-101.

Varennes, A. 2003. Soil Productivity and Environment. Lisbon: Escolar Editora.

Wong, M. H. 1985. Phytotoxicity of refuse compost during the process of maturation. Environmental Pollution Series A 37: 159-174.

Yilmaz, E., and Z. Alagoz. 2010. Effects of short-term amendements of farmyard manure on some soil properties in the Mediterranean region of Turkey. Journal of Food Agriculture \& Environment 8: 859-862.

Zucconi, F., and M. de Bertoldi 1987. Composts specifications for the production and characterization of composts from municipal solid waste. In: Compost: Quality and Use, eds. M. de Bertoldi, M. P. Ferranti, P. L’Hermite, and F. Zucconi, pp. 30-50. London: Elsevier Applied Science. 